\title{
Role of Hypoxia Inducible Factor-1 Alpha in Early Stage Renal Failure and Its Relationship with Biochemical and Inflammatory Parameters
}

\author{
Erken Dönem Böbrek Yetmezliğinde Hipoxia İnducible Factor-1 Alfa Düzeyinin Rolü \\ ve Biyokimyasal ve Enflamatuvar Parametrelerle İlişkisi
}

\author{
(1) Hanife Usta Atmaca ${ }^{1}$, (D) Osman Oğuz ${ }^{2}$ \\ 1istanbul Training and Research Hospital, Clinic of Internal Medicine, İstanbul, Turkey \\ 2Istanbul Training and Research Hospital, Clinic of Biochemistry, ístanbul, Turkey
}

\begin{abstract}
Introduction: Hypoxia-inducible factor-1 (HIF-1) is the protein product of the gene with the same name that is induced by hypoxia and induces a series of reactions that act in the adaptive response of the cell. HIF-1 activation is a primary defense mechanism against the hypoxia of the tissue. In general, it is activated when tissue oxygenation is disrupted. Tissue hypoxia in kidney disease provides adaptation to the current situation by activating the HIF-1 alpha level. In this report, it was aimed to measure HIF-1 alpha levels in early stage renal failure patients, compare them with healthy volunteers, and evaluate the relationship between HIF-1 alpha and other biochemical and inflammatory parameters.
\end{abstract}

Methods: This study included 22 healthy subjects (male/ female; 8/14) as the control group and 25 patients (male/ female; 11/14) who are followed up in the outpatient clinic with the diagnosis of early stage renal failure (glomerular filtration rate $60-90 \mathrm{~mL} / \mathrm{min} / 1.73 \mathrm{~m}^{2}$ ). HIF-1 alpha level, biochemical parameters [glucose, creatinine, uric acid, aspartate aminotransferase (AST), alanine aminotransferase (ALT)], hemoglobin and inflammatory parameters [C-reactive protein (CRP), neutrophil/lymphocyte ratio], platelet count (PLT), platelet parameters [mean platelet volume (MPV), plateletcrit (PCT) and platelet distribution width (PDW)] were viewed in venous blood samples in both groups, and results were compared using descriptive statistical methods as well as Mann-Whitney U, chi-square, student t-test.

Results: HIF-1 alpha, glucose, AST, ALT, gamma-glutamyl transpeptidase (GGT), PLT, MPV, PCT and PDW values were not statistically significantly different $(p>0.05)$ among the case and control groups. There was no statistically significant correlation ( $p>0.05$ ) between HIF-1 alpha and glucose, urea, creatinine, AST, GGT, CRP, neutrophile/lymphocyte ratio, PLT, MPV, PCT, PDW values.

\section{öz}

Amaç: Hypoxia-inducible factor-1 (HIF-1) aynı isimli genin proteini olup hipoksiyle indüklenerek hücrenin adaptif cevabını sağlayan bir dizi reaksiyonu bașlatır. Aktivasyonu dokudaki hipoksiye karşı primer defansif mekanizmadır. Genellikle doku oksijenasyonunun bozulduğu patolojik durumlarda aktive olur. Böbrek hastalığında oluşan doku hipoksisi HIF-1 alfa düzeyini yükselterek mevcut duruma adaptasyonu sağlar. Burada erken dönem böbrek yetmezliğinde HIF-1 alfa düzeyine bakılarak sağlıklı gönüllülerle karşılaștırılması ve HIF-1 alfa düzeyinin diğer biyokimyasal ve enflamatuvar parametreler ile olan ilişkisinin değerlendirilmesi amaçlanmıștır.

Yöntemler: Çalışmaya ayaktan takipli, erken dönem böbrek yetmezliği tanısı almış (glomerular filtration rate $60-90 \mathrm{~mL}$ / $\mathrm{min} / 1,73 \mathrm{~m}^{2}$ ) olan hastalardan randomize edilmiş (erkek/ kadın; 11/14) 25 hasta ile 22 sağlıklı (erkek/kadın; 8/14) gönüllü alınmıştır. Her iki grupta venöz kan örneklerinde HIF1 alfa düzeyi, biyokimyasal parametreler [glukoz, kreatinin, ürik asit, aspartat transaminaz (AST), alanin transaminaz (ALT)], hemoglobin ve enflamatuvar parametreler [C-reaktif protein (CRP), nötrofil/lenfosit oranı], trombosit sayımı (PLT), trombosit parametreleri [ortalama trombosit hacmi (MPV), plateletcrit (PCT) and (PDW)] bakıldı. Sonuçlar tanımlayıcı istatistik metotların yanı sıra Mann-Whitney U, ki-kare ve student t-testi kullanılarak karşılaștırıldı.

Bulgular: Olgu ve kontrol grubunda HIF-1 alfa değeri, glukoz, AST, ALT, GGT, PLT, MPV, PCT, PDW değerleri anlamlı ( $p>0,05)$ farklılık göstermemiștir. HIF-1 alfa ile glukoz değeri, üre, kreatinin, AST, GGT, CRP, nötrofil/lenfosit oranı, PLT, MPV, PCT, PDW değerleri arasında anlamlı $(p>0,05)$ korelasyon gözlenmemiștir. HIF-1 alfa ile ürik asit değeri arasında anlamlı $(p<0,05)$ negatif korelasyon gözlenmiștir. HIF-1 alfa ile ALT ve hemoglobin değeri arasında anlamlı $(p<0,05)$ pozitif korelasyon gözlenmiștir.
Address for Correspondence/Yazıșma Adresi: Hanife Usta Atmaca, İstanbul Training and Research Hospital, Clinic of Internal Medicine, İstanbul, Turkey

Phone: +90 5303122973 E-mail: hanifeusta@yahoo.com ORCID ID: orcid.org/0000-0002-6591-4810

Cite this article as/Atıf: Atmaca HU, Oğuz 0. Roleo Hypoxia Inducible Factor-1 Alpha in Early Stage Renal Failure and Its Relationship with Biochemical and Inflammatory Parameters. İstanbul Med J 2019; 20(1): 58-62.
Received/Geliș Tarihi: 30.10 .2018 Accepted/Kabul Tarihi: 07.12.2018

(c) Copyright 2019 by the Istanbul Training and Research Hospital/Istanbul Medical Journal published by Galenos Publishing House.

(C) Telif Hakkı 2019 Istanbul Ĕgitim ve Araștırma Hastanesi/Istanbul Tıp Dergisi, Galenos Yayınevi tarafından basılmıștır. 
Conclusion: It is known that chronic hypoxia is an important factor in the progression of chronic renal diseases regardless of the underlying cause. It was assumed that the factors including normotension, normal hemoglobin level and the presence of medical therapy reducing oxidative stress (angiotensin converting enzyme inhibitors and angiotensin receptor blockers) in the patientsimproved renal hypoxia and therefore affected the results of this study.

Keywords: Hypoxia-inducible factor-1 alpha, early stage renal failure, renal hipoxia

\section{Introduction}

Chronic renal failure is a disease in which various etiologies cause irreversible nephron loss in the kidneys and its frequency increases in the world. The oxygen distribution in the kidney is heterogeneous in parallel with the blood distribution and plays a role in many physiological and pathological events of the kidney. Hypoxia-inducible factor-1 (HIF1) alpha is a transcription regulator of metabolic processes such as angiogenesis, erythropoesis, iron and glucose metabolism of the kidney.

HIF-1 alpha gene protein, which activates the genes that are induced by hypoxia in humans, is one of the most well-known elements of the HIF-1 gene family. HIF-1 is a heterodimeric protein and consists of HIF1 alpha (HIF-2 alpha and HIF-3 alpha are homologous) and HIF-1 $\beta$ (which is in nucleus) subunits. The stability and activity of the alpha subunit of HIF-1 is provided by post-transcriptional modifications such as hydroxylation, ubiquitination, acetylation and phosphorylation (2). In hypoxic conditions, non- hydroxylated HIF-1 alpha subunit becomes stable and activates with coactivators such as CAMP, protein/p300 and passes to the nucleus. It combines with the HIF-1 $\beta$ subunit to regulate the expression of the hypoxia response genes. HIF-1 was first described as a transcription complex that causes increase in erythropoietin (EPO) in response to hypoxia $(3,4)$. In recent studies, it was found that HIF1 proteins were the key regulator of the transcriptional activation responses to hypoxia of many genes related to adaptation to low oxygen pressure in cells and tissues, cell survival and proliferation, angiogenesis, erythropoesis, glucose intake and iron metabolism (5,6). Therefore, HIF-1 alpha is accepted as an adaptive response to pathophysiological processes in early chronic kidney disease (CKD).

In this study, HIF-1 alpha level in patients with early CKD with glomerular filtration rate (GFR) $60-90 \mathrm{~mL} / \mathrm{min} / 1.73 \mathrm{~m}^{2}$ were compared with healthy volunteers and the relationship between HIF-1 alpha level and biochemical and inflammatory parameters was discussed.

\section{Methods}

The study was approved by the ethics committee of İstanbul Training and Research Hospital (date: 15.12.2017 no: 1149). Twenty five patients with CKD with GFR between $60-90 \mathrm{~mL} / \mathrm{min} / 1.73 \mathrm{~m}^{2}$ (male/female: $11 / 14$, mean age: $70 \pm 8.2$ years) who were followed up in the outpatient clinic and 22 healthy volunteers (male/female: $8 / 14$, mean age: $67.3 \pm 7.3$ years) were included in the study.

In the patient group, 14 patients had diabetes mellitus (DM) (for 20 years and longer), 5 patients had hypertension (regulated with treatment) and 6 patients had no etiology. In patients with DM, 1 patient was
Sonuç: Kronik hipoksinin altta yatan sebepten bağımsız olarak kronik böbrek hastalıklarının ilerlemesinde önemli bir faktör olduğu bilinmektedir. Hasta grubunun normotansif olması, hemoglobin düzeyinin normal olması, hastada oksidatif stresi azaltan medikal tedavinin (anjiyotensin dönüștürücü enzim inhibitörü ve anjiyotensin reseptör blokeri kullanımı) bulunması gibi sebeplerin sonuçları etkilediği ve renal hipoksiyi iyileștirdiği varsayılmıștır.

Anahtar Kelimeler: Hypoxia-inducible factor-1 alfa, erken dönem böbrek yetmezliği, renal hipoksi

using sulphonylurea (gliclazide $30 \mathrm{mg}$ ) and 13 were using insulin. All patients were treated with angiotensin converting enzyme inhibitors or angiotensin receptor blockers. All patients were normotansive. Patients with active malignancy or history of malignancy, cardiac failure, acute cardiac ischemia (within last 6 months), chronic obstructive pulmonary disease, high blood pressure or a history of irregular blood pressure and smokers or ex-smokers were exluded from the study. Non-high density lipoprotein cholesterol levels were normal in all patients.

Oral and written informed consents were obtained from all participants. Blood pressure measurements performed twice in the morning visits while the participants were in the sitting position were normal. Venous blood samples were taken from the antecubital vein following 10 hours of fasting in the sitting position in the morning. Serum HIF-1 alpha, fasting blood glucose, urea, creatinine, uric acid, aspartate aminotransferase (AST), alanine aminotransferase (ALT), gamma-glutamyl transferase (GGT) and C-reactive protein (CRP) levels and hemogram were measured.

HIF-1 alpha level was measured with ELISA (enzym linked immunosorbent assay) method in the Synergy HT device. Other parameters were measured at one time with spectrophotometric method in the Beckman Coulter AU 2700 plus (Beckman Coulter, Inc., Fullerton, USA) autoanalyzer.

\section{Statistical Analysis}

Descriptive statistics of the data were expressed as mean, standard deviation, median, lowest value, highest value, frequency and ratio. Distribution of the variables was checked by the Kolmogorov-Simirnov test. In the analysis of quantitative independent data, independent t-test and Mann-Whitney $U$ test were used. In the analysis of qualitative independent data, the chi-square test was used. In correlation analysis, the Spearman correlation analysis was used. In the analysis of the data, SPSS 22.0 package program was used.

\section{Results}

There was no difference between groups in terms of mean age and gender distribution $(p>0.05)$. There was no difference between groups in terms of HIF-1 alpha, fasting blood glucose, AST, ALT and GGT levels, platelet (PLT) count, mean platelet volume (MPV), plateletcrit (PCT) and platelet distribution width (PDW) values ( $p>0.05)$ (Table 1).

Urea, creatinine, uric acid and CRP levels and neutrophil/lymphocyte $(\mathrm{N} / \mathrm{L})$ ratio were significantly higher in the patient group than in the control group $(p<0.05)$. Hemoglobin level was significantly lower in the patient group than in the control group $(p<0.05)$ (Table 1). 
Table 1. Comparison of the charecteristics and laboratory data in patient and control groups

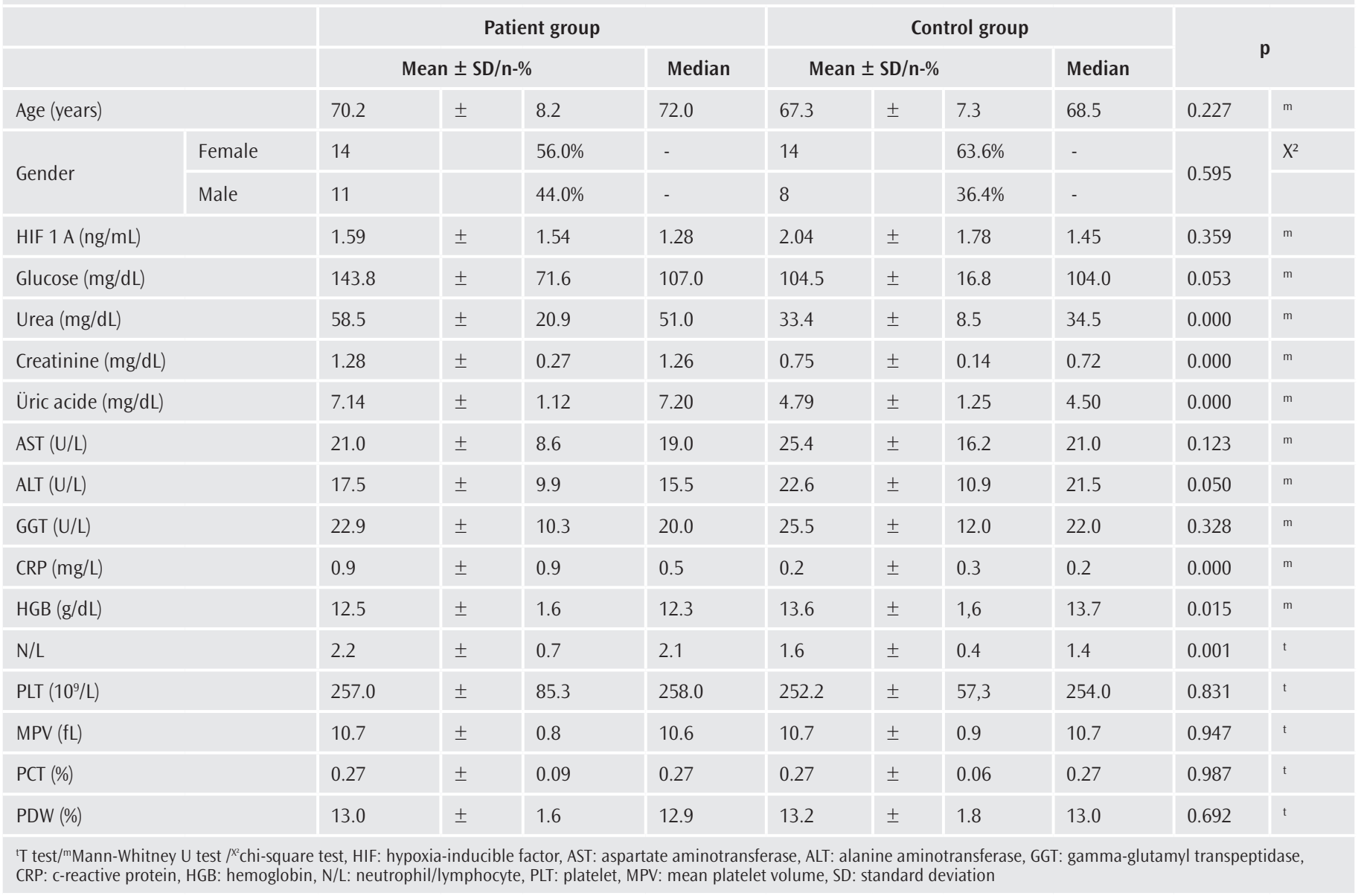

Table 2. Correlation between hypoxia-inducible factor-1 A level and other paramethers

\begin{tabular}{|c|c|c|c|c|c|c|}
\hline & & Glucose & Urea & Creatinine & Uric acide & AST \\
\hline \multirow{2}{*}{ HIF $1 \mathrm{~A}$} & $r$ & 0.049 & -0.268 & -0.281 & -0.310 & 0.183 \\
\hline & $\mathrm{p}$ & 0.745 & 0.069 & 0.056 & 0.048 & 0.225 \\
\hline & & ALT & GGT & CRP & HGB & $\mathrm{N} / \mathrm{L}$ \\
\hline \multirow{2}{*}{ HIF $1 \mathrm{~A}$} & $r$ & 0.367 & 0.032 & -0.054 & 0.361 & -0.143 \\
\hline & $\mathrm{p}$ & 0.012 & 0.832 & 0.732 & 0.015 & 0.354 \\
\hline & & PLT & MPV & РCT & PDW & D vіт \\
\hline \multirow{2}{*}{ HIF 1 A } & r & -0.181 & 0.157 & -0.052 & -0.088 & 0.156 \\
\hline & $\mathrm{p}$ & 0.235 & 0.302 & 0.734 & 0.564 & 0.342 \\
\hline \multicolumn{3}{|c|}{ Spearman correlation } & & & & \\
\hline
\end{tabular}

There was no significant correlation between HIF-1 alpha level and fasting blood glucose, urea, creatinine, AST, GGT, CRP levels, N/L ratio, PLT count, MPV, PCT, PDW values ( $p>0.05)$ (Table 2).

There was a significant negative correlation between HIF-1 alpha and uric acide levels $(p<0.05)$. There was a significant positive correlation between HIF-1 alpha, ALT and hemoglobin levels (Table 2).

\section{Discussion}

Increase in HIF-1 alpha is the primary defense mechanism of kidneys against hypoxia. In this study, no significant difference was found between healthy individuals and patients with early CKD in terms of HIF-1 alpha level. Normal hemoglobin levels in the patients and positive effects of the medications could explain this finding. 
It is known that chronic hypoxia is an important factor in the progression of CKD regardless of underlying cause (7). It was shown that oxygen demand-supply mismatch occurs before visible damage occurs in kidneys in kidney diseases (8). Direct regulative effect of transforming growth factor (TGF) beta 1, a powerful profibrotic factor, on fibrogenic factors and the role of inflammation are the mechanisms of the development of renal fibrosis with the increase of HIF.

In contrast to the potential profibrotic role, there are studies showing that HIF-1 alpha may have a protective function with pro-angiogenic and cytoprotective effects under some CKD conditions (9-11). HIF-1 alpha can be found in the kidney in physiological conditions, and also it has been shown to increase in all cases (anemia, tumor, etc.) causing hypoxia in kidneys. Although kidney is an organ with high blood flow, the oxygen tension of the tissue in the parenchyma is lower than in other organs (12). This is due to the parallel placement of arterial and venous pre and post glomerular vessels (13). This array allows oxygen to pass through the arteries to the veins via the shunt, and cause the medullar region of kidney to be prone to hypoxia in case of the breakdown of blood flow to the kidney.

Anemia is one of the leading causes of hypoxia in the kidney. Anemia is a common condition in CKD. In addition to the lack of EPO, functional iron deficiency contributes to the development of this condition. Kidney acts as the most important physiological oxygen sensor in the regulation of erythropoesis. EPO is a hematopoietic growth factor and regulates the production of red blood cells. EPO mRNA levels have been shown to increase 1000 times or more in kidney and liver cells in severe hypoxic conditions and HIF-1 alpha has been defined as the main transcriptional mediator of this process (1). In recent studies, it was shown that inhibition of HIF-1 alpha hydroxylase not only increased serum EPO levels but also improved iron intake and metabolism. The transferrin and its receptor were previously shown to be the direct transcriptional targets of HIF $(14,15)$. The lack of EPO is the main cause of anemia in CKD and anemia accelerates the decrease in kidney function by inducing tubulointerstitial hypoxia (16). In this study, normal hemoglobin level (mean $12.5 \mathrm{mg}$ ) in the patient group was considered as protective against hypoxic conditions in the kidney. A number of genes that play a role in pathophysiological changes in the arteries and kidneys in hypertension are activated by HIF. Many genes (EPO, endothelin-1, vascular endothelial growth factor, tumor necrosis factor, TGF, collagen-1) are activated by HIF, which plays a role in the negative pathophysiological changes in blood vessels and kidneys in hereditary hypertension $(17,18)$. Normotension prevents the increase in HIF levels. The blockage of the renin angiotensin system protects the blood flow to the peritubular capillary. The increase of angiotensin II in renal diseases increases renal oxidative stress by stimulating the oxidation of nicotinamide adenine dinucleotide phosphate (NADPH). This prevents the efficient use of oxygen in tubular cells. Increased oxidative stress products lead to decreased nitric oxide (NO). Adler and Huang (3) showed that reduced NO increased energy consumption by two times by stimulating mitochondrial respiration and resulted in tissue hypoxia. Another experimental study showed that perfusion of low dose ang-2 increased NADPH oxidase activity in renal cortex, caused renal vasoconstriction, induced ang-2, and induced cortical hypoxia due to inadequate utilisation of oxygen for tubular sodium transport (19). CKD is associated with oxidative stress. Renal anemia is a condition that also increases oxidative stress. Norman et al. (20) showed that blockade of RAS protected peritubular blood flow and tissue oxygenation. Manotham et al. (21) showed improved peritubular capillary blood flow and oxygenation with angiotensin blocker olmesartan in the remnant renal model.

RAS inhibitors also act as antioxidants and play a healing role in mitochondrial uncoupling, lead to more efficient use of oxygen and improve mitochondrial respiration. They lead to more efficient use of oxygen which is necessary for sodium transport (22). In this study, all of the patients were using ARB or ACE inhibitors. This treatment decreases ang-2 levels and leads to renal recovery which were considered to affect HIF-1 alpha level in this study. Also, in this study, there was no difference between groups in terms of thrombocyte count and its parameters. As known, PLT parameters have prognostic and diagnostic significance in many diseases. Exposure of PLTs to uremic toxins causes functional and numerical changes which increase complications, especially cardiovascular complications in CKD (23). We did not find difference between groups which could be explained by the presence of early CKD and consequent short-term exposure to uremic toxins in the patients. In our study, inflammatory parameters (CRP, N/L) were found to be significantly higher in the patient group but no correlation was found between these parameters and HIF-1 alpha level. This could be explained by the positive contribution of the above mentioned healing factors.

\section{Conclusion}

As a result, HIF-1 alpha is in the center of the cellular response to hypoxia and activates transcription of genes that encode proteins that mediate adaptive responses to decreased oxygen presence in tissue. In the early stages of CKD, HIF-1 alpha increases due to the effects of lack of EPO, hypokalemia, anemia, increased ang- 2 and other oxidative stress factors increase and contributes to the progression of the disease. Supportive studies will help us better understand the role of HIF-1 alpha, and in the future, HIF-1 alpha may become the target of treatments that slow down the progression of disease.

Ethics Committee Approval: This study was approved by the İstanbul Training and Research Hospital Ethics Committee in 15.12.2017 (no: 1149).

Informed Consent: Oral and written informed consents were obtained from all participants.

Peer-review: Internally peer-reviewed.

Author Contributions: Concept - H.U.A.; Design - H.U.A.; Supervision - H.U.A.; Resources - H.U.A.; Materials - 0.O.; Data Collection and/or Processing - H.U.A., O.O.; Analysis and/or Interpretation - H.U.A., O.O.; Literature Search - H.U.A.; Writing Manuscript - H.U.A.; Critical Review - H.U.A.

Conflict of Interest: No conflict of interest was declared by the authors.

Financial Disclosure: The authors declared that this study received no financial support. 


\section{References}

1. Wang, GL, Jiang, BH, Rue EA, Semenza GL. Hypoxia-inducible factor 1 is a basic-helix-loop-helix-PAS heterodimer regulated by cellular 02 tension. Proc. Natl Acad Sci 1995; 92: 5510-4.

2. Manotham K, Tanaka T, Ohse T, Kojima I, Miyata T, Inagi R, et al. Biologic role of HIF-1 in the renal medulla. Kidney Int 2005; 67: 1428-39.

3. Adler S, Huang $\mathrm{H}$. Impaired regulation of renal oxygen consumption in spontaneously hypertensive rats. J Am Soc Nephrol 2002; 13: 1788-94.

4. Semenza GL, Wang GL. A nuclear factor induced by hypoxia via de novo protein synthesis binds to the human erythropoietin gene enhancer at a site required for transcriptional activation. Mol Cell Biol 1992; 12: 5447-54.

5. Schofield CJ, Ratcliffe PJ. Oxygen sensingby HIF hydroxylases. Nat Rev Mol Cell Biol 2004; 5: 343-54.

6. Wenger RH, Stiehl DP, Camenisch G. Integration of oxygen signaling at the consensus HRE. Sci STKE 2005; 2005: re12.

7. Fine LG, Bandyopadhay D, Norman JT. Is there a common mechanism for the progression of different types of renaldiseases other than proteinuria? Towards the unifying theme of chronic hypoxia. Kidney Int Suppl 2000; 75: S22-6.

8. Matsumoto M, Tanaka T, Yamamoto T, Noiri E, Miyata T, Inagi R, et al. Hypoperfusion of peritubular capillaries induces chronic hypoxia before progression of tubulointerstitial injury in a progressive model of rat glomerulonephritis. J Am Soc Nephrol 2004; 15: 1574-81.

9. Tanaka T, Kojima I, Ohse T, Ingelfinger JR, Adler S, Fujita T, Nangaku M. Cobalt promotes angiogenesis via hypoxia-inducible factor and protects tubulointerstitium in the remnant kidney model. Lab Invest 2005; 85: 1292307.

10. Tanaka T, Matsumoto M, Inagi R, Miyata T, Kojima I, Ohse T, et al. Induction of protective genes by cobalt ameliorates tubulointerstitial injury in the progressive Thy1 nephritis. Kidney Int 2005; 68: 2714-25.

11. Yuan HT, Li XZ, Pitera JE, Long DA, Woolf AS. Peritubular capillary loss after mousea cute nephrotoxicity correlates with down-regulation of vascular endothelial growthfactor-A and hypoxia-inducible factor-1 alpha. Am J Pathol 2003; 163: 2289-301.
12. Lubbers DW, Baumgartl H. Heterogeneitiesand profiles of oxygen pressure in brain andkidney as examples of the p02 distribution in thelivingtissue. Kidney Int 1997; 51: 372-80.

13. Zhang W, Edwards A. Oxygen transport acrossvasarecta in therenalmedulla. Am J Physiol Heart Circ Physiol 2002; 283: H1042-55.

14. Lok CN, Ponka P. Identification of a hypoxia response element in the transferin receptor gene. J Biol Chem 1999; 274: 24147-52.

15. Rolfs A, Kvietikova I, Gassmann M, Wenger RH. Oxygen-regulated transferin expression is mediated byhypoxia-inducible factor-1. J Biol Chem 1997; 272 : 20055-62.

16. Astor BC, Muntner P, Levin A, Eustace JA, Coresh J. Association of kidney function with anemia: The Third National Health andNutrition Examination Survey (1988-1994). ArchIntern Med 2002; 162: 1401-8.

17. Ratcliffe PJ, O'Rourke JF, Maxwell PH, Pugh CW. Oxygensensing, hypoxiainducible factor-1 andtheregulation of mammalian gene expression. J Exp Biol 2000; 201: 1153-62.

18. Shih SC andClaffey KP. Hypoxia-mediatedregulation of gene expression in mammaliancells. Int J Exp Pathol 1998; 79: 347-57.

19. Welch WJ, Blau J, Xie H, Chabrashvili T, Wilcox CS. Angiotensin-induceddefects in renaloxygenation: Role of oxidativestress. Am J Physiol Heart Circ Physiol 2005; 288: H22-H8.

20. Norman JT, Stidwill R, Singer M, Fine LG. Angiotensin II blokade augments renal cortical microvascular p02 indicating a novel potential protective action. Nephron Physio 2003; 194: 39-46.

21. Manotham K, Tanak T, Matsumoto M, Ohse T, Miyata T, Inagi R, et al. Evidence of Tubular hypoxia in the early phase in the remnant kidney model. L Am Soc Nephrol 2004; 15: 1277-88.

22. Welch WJ, Baumgartl H, Lubbers D, Wilcox CS. Renal oxygenation defect in the spontaneously hypertensive rat: Role of AT1 receptors. Kidney Int 2003; 63: 202-8.

23. Boccardo P, Remuzzi G, Galbusera M. Platelet dysfunction in renal failure. Semin Thromb Hemost 2004; 30: 579-89. 